\title{
Designing and Building Electronic Medical Record (EMR) on Web-Based in Primary Health Services
}

\author{
Sustin Farlinda* \\ Department of Health \\ Politeknik Negeri Jember \\ Jember, Indonesia \\ sustin@polije.ac.id
}

\author{
Feby Erawantini \\ Department of Health \\ Politeknik Negeri Jember \\ Jember, Indonesia \\ feby_era@yahoo.co.id \\ Destya Putri Zakiah Utami \\ Department of Health \\ Politeknik Negeri Jember \\ Jember, Indonesia \\ destyapzu@gmail.com
}

\author{
Saiful Anwar \\ Department of Engeenering \\ Politeknik Negeri Jember \\ Jember, Indonesia \\ saiful_anwar@polije.ac.id
}

\begin{abstract}
Primary health services in Jember consist of community health centers (puskesmas) and clinics and most of them are still manual systems, namely registration of old patient files takes a relatively long time, old patients who do not carry the treatment card are new patients. This will affect the quality of service to patients and also waste storage of files, especially patients who are controlled routinely and patients with chronic disease. In addition to drug management, pharmacists who have problems when the drug stock runs out and do not notify the clinic will affect the doctor's performance in prescribing to patients. The purpose of this study was to design and build an Electronic Medical Record Application, especially the General Section in Primary Health Services with a case study at Puskesmas Patrang Jember. The design method in making this application is to use the waterfall model. The stages in this model include analysis, design, coding and testing. In the analysis stage, the data used interviews, observation and documentation. The stage of designing uses flowchart, data flow diagram (DFD) and entity relationship diagram (ERD). The results of this study are the general poly Electronic Medical Records in Primary Health Services. By making electronic medical records, it is hoped that it can be implemented and help overcome problems that exist in Primary Health Services so that performance becomes more effective and efficient and data integrated.
\end{abstract}

Keywords—electronic medical records, waterfall, primary health services

\section{INTRODUCTION}

This template, modified in MS Word 2007 and saved as a "Word 97-2003 Document" for the PC, provides authors with most of the formatting specifications needed for preparing electronic versions of their papers. All standard paper components have been specified for three reasons: (1) ease of use when formatting individual papers, (2) automatic compliance to electronic requirements that facilitate the concurrent or later production of electronic products, and (3) conformity of style throughout a conference proceedings. Margins, column widths, line spacing, and type styles are built-in; examples of the type styles are provided throughout this document and are identified in italic type, within parentheses, following the example. Some components, such as multi-leveled equations, graphics, and tables are not prescribed, although the various table text styles are provided. The formatter will need to create these components, incorporating the applicable criteria that follow.

Development of the world of information technology is very rapid, this has led to changes in all fields, namely the shift from manual systems to electronic-based systems in health services globally. Electronic Medical Record (EMR) is a long-term record of patient health information generated by one or more health care providers when patients visit health care facilities (Hikmah and Farlinda [6].

The use of information systems in the health sector lags behind other sectors such as banking and finance, aviation transportation services and the telecommunications industry. The 2008 survey shows that only about $10 \%$ of public hospitals in the US already use both a comprehensive EHR system and a basic EHR. The adoption rate is roughly the same in European countries. The 2007 survey only about $11.9 \%$ of public hospitals in Austria and $7.0 \%$ of German hospitals used the comprehensive EHR. In the same year, only about $10.1 \%$ of hospitals in Japan had adopted the EHR. In Korea, approximately $80.3 \%$ of teaching hospitals and general hospitals use CPOE but only $9 \%$ use EHR comprehensively. Meanwhile in Indonesia at this time, RME is also widely applied in hospitals. For the application of RME in Primary Health Services, it has only been started since 2010. Meanwhile, in Jember Regency itself, $30.61 \%$ or 15 of 49 Puskesmas have implemented SIMPUS (Puskesmas Management Information System). Puskesmas Patrang is one of the Puskesmas that has not implemented SIMPUS.

Puskesmas Patrang is a Puskesmas close to the city center, with an average number of patients per day around 100 people. And most of them go to the General clinic. In the process of serving patients, it is very related and requires medical records. Puskesmas Patrang organizes paper-based medical records. This method often creates several obstacles, both in terms of time and in terms of data accuracy. Hing [7]

When viewed from a time perspective, manual processing of data takes longer than the computerized method. When data processing takes a long time, the impact of service to patients 
is not effective and efficient. Likewise, when viewed from an accuracy point of view, manual methods often result in invalid information. Based on the preliminary study, Puskesmas Patrang needed a web-based application to minimize the existing problems, so the researchers conducted a research entitled Web-based Electronic Medical Record Designing for Primary Health Services ".

In this research the research problem could be formulated as follows 'How to design and build Web-based Electronic Medical Records in Primary Health Services. Research Objective is Designing and building Electronic Medical Records on Web Based in Primary Health Services

\section{METHOD}

The method used in designing and making electronic medical records is the Waterfall Model. The real name of the Waterfall Model is the Linear Sequential Model. This model is often referred to as the classic life cycle. It is called a waterfall because the steps that are passed must wait for the completion of the previous stage and run sequentially. Roger S. Pressman [15]

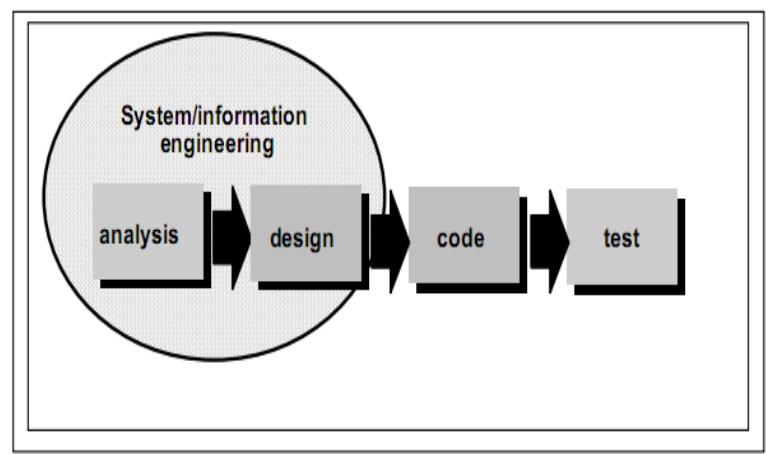

Fig. 1. Waterfall Models

Roger S. Pressman [15] breaks the waterfall model into the following stages:

\section{A. Analysis}

Needs gathering is intensified and focused, especially on software. In order to understand the nature of the program being built, the analysis must understand the information domain, the behavior, for the work, and the required interfaces. Requirements for both systems and software are documented and reviewed with the customers.

\section{B. Designing}

In this process the requirements are converted into representations in the form of software design before the coding process begins. The design must be able to implement the requirements mentioned in the previous stage. This process must be documented in the form of software requirements.

\section{Coding}

The designing is converted into a form that can be understood by a machine, that is, into a programming language through the coding process. This stage is the implementation of the design stage which is technically done by the programmer. Gondodiputro [2]

\section{Testing}

Then after the coding stage is complete, all software functions are tested so that the software is free from errors and the results must be correct. This stage is the testing stage and the support stage, which means that the system that has been created from the results of problem analysis has gone through the design stages, then the coding then enters the system testing, so that it will be known what the performance results of this new system are compared to the old system, then it can also be seen whether there are still weaknesses in this new system will be developed by the next researcher.

\section{RESULTS AND DISCUSSION}

\section{A. Analysis}

At this stage, the analysis of the current system is carried out through elaborate the results of interviews and observation. The system currently running in recording and processing medical records for Poli general patients is still manual, so it is not optimal. The following is a Flowchart of the Medical Record Service System Manual for General Poli with a case study at Puskesmas Patrang Jember

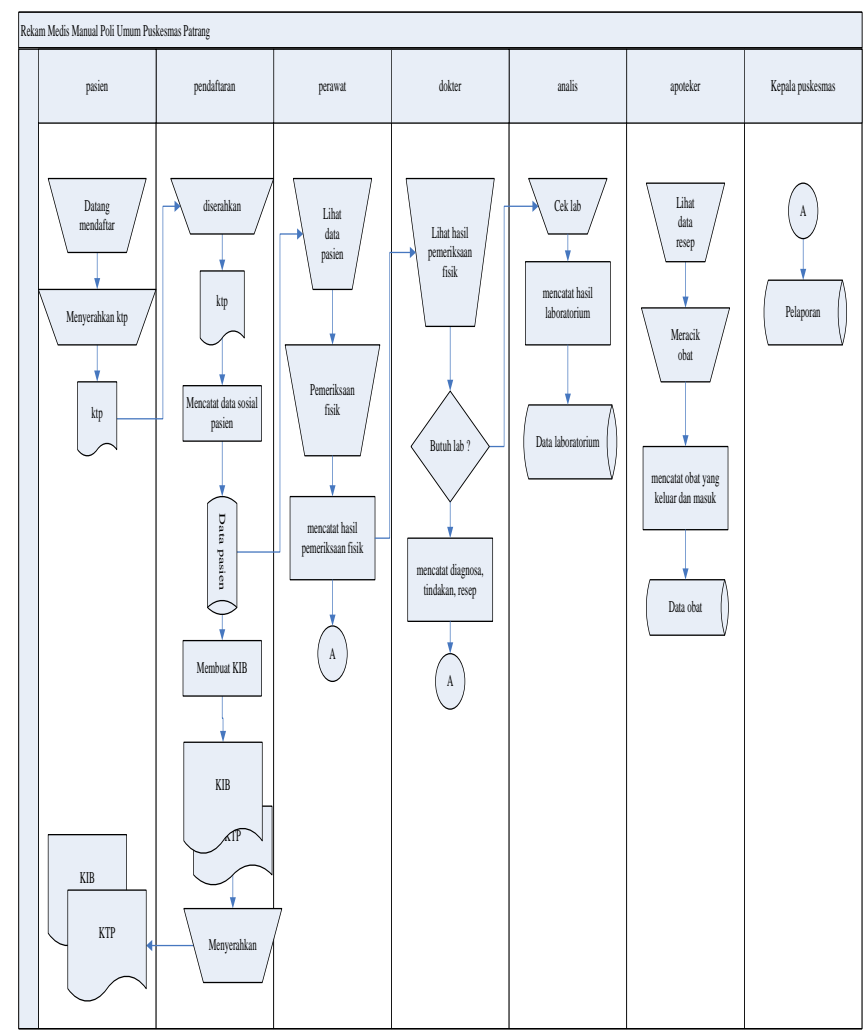

Fig. 2. Flowchart system before Designing

\section{B. Designing}

From the results of the system analysis, it was found that the development was a Flowchart Design of an Electronic Medical Record System with a case study: Public Poli Puskesmas Patrang Jember so that a Data Flow Diagram can be made of the system at figure. 3 


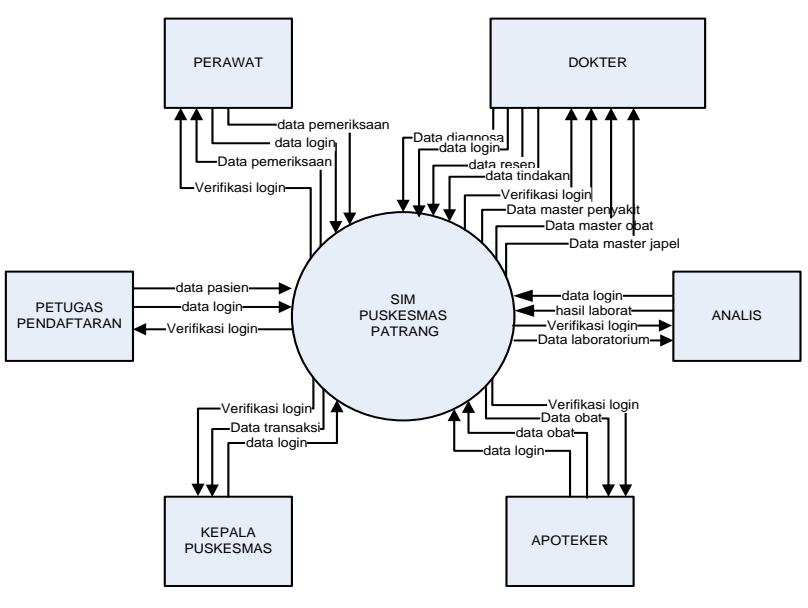

Fig. 3. Data Flow Diagram of EMR

\section{Coding}

This stage is the implementation of the designing into loading applications with the PHP programming language framework CI with the following results

\section{1) Examination page}

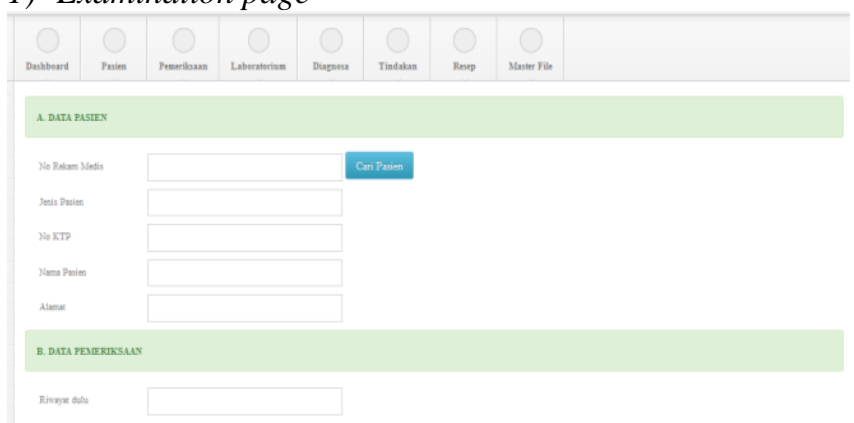

Fig. 4. Examination Page

\section{2) Actions page}

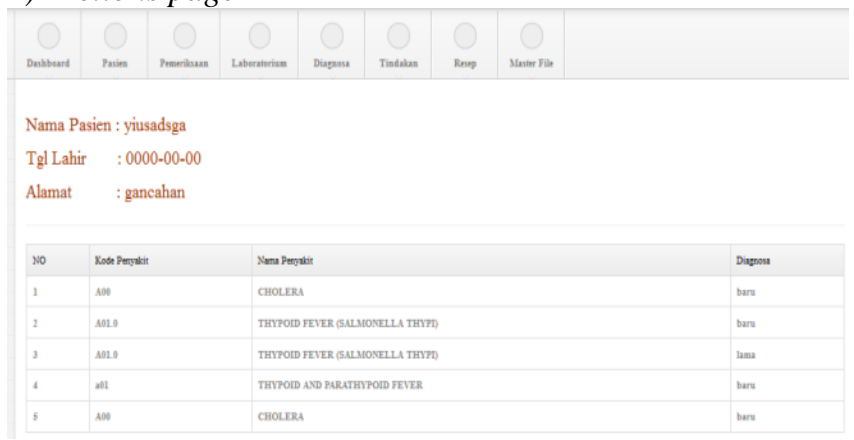

Fig. 5. Action Page

\section{3) Recipe page}

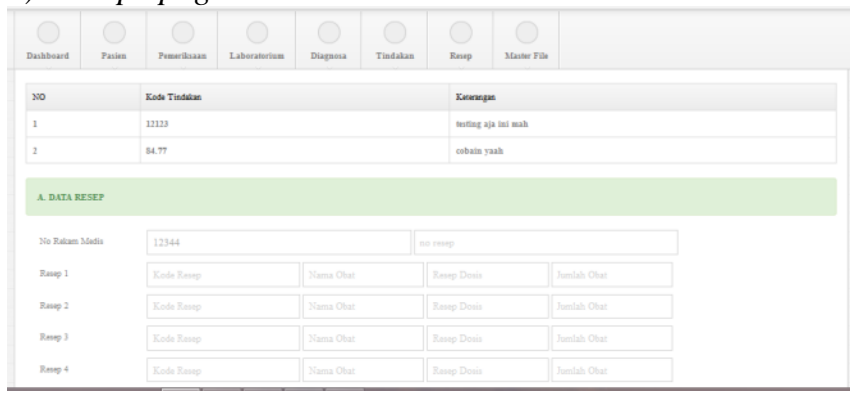

Fig. 6. Recipe Page



Fig. 7. Laborat Page

\section{Testing}

The final stage of this process is testing. The testing process focuses on the functionality and internal logic of the software and ensures that all statements are tested. The system is tested to find faults and ensure that the limited input will provide actual results according to the required results. Testing of the Electronic Medical Records for Public Polytechnic Public Health Center Patrang that has been made is by using the Black-box technique. According to Roger $\mathrm{S}$ Pressman [8], black-box testing is a test that focuses on the functional requirements of the software. In the tests carried out at the Patrang Health Center, which was presented directly whether the functions of the web-based application that had been executed were in accordance with functional needs or not

\section{CONCLUSION}

The conclusion of this study is that the application has been produced as the output of this study and provides solutions to the results of the analysis obtained based on the results of testing. This application can be developed by adding reporting, backup and restore facilities.

\section{REFERENCES}

[1] Budi, S. C. 2011. Management of Work Unit Mdical Record. Yogyakarta: Quantum Sinergis Media

[2] Gondodiputro, S. 2007. "Medical Record and Health Information System at Care center". Fakultas Keanalisan Universitas Padjajaran. Bandung. https://bidankomunitas.files.wordpress.com. Acess AT 1 June 2015.

[3] S Farlinda, MC Roziqin, F Hikmah, Y Pratama, 2020, "Designing and Creating Web-Based Outpatient Information System At Panti Community Health Center (Puskesmas) Jember", https://iopscience.iop.org/article/10.1088/17426596/1569/2/022012/meta

[4] S Farlinda, B Wahab, 2019. “ Designing and Making Website Yonif 509 clinic at Jember For Promotion using Waterfall Method" https://jurkes.polije.ac.id/index.php/journal/article/view/65

[5] Hikmah, F., dan S. Farlinda. 2014. EHR Electronic Health Record untuk Rekam Medik. Jember.

[6] Hing, E., dan C. Hsiao. 2010. "Electronic Medical Record Used by Office Based Physicians and Their Practices". Health Care Statistics. United States. http://1246.124.22/nchs/data/nhsr/nhsr023.pdfDiakses pada 29 April 2015.

[7] Jogiyanto, H.M., 2005, Analysis and Designing Information System: Approach with Teory Structured and Practice of Bussines application, Yogyakarta: ANDI.

[8] Kadir, A. 2009. Basic Design and Implementation of Relational Databases Fundamental of Designing and Implementation of Relational Database. Yogyakarta: Andi.

[9] Kementerian Kesehatan RI. 2012. "Roadmap of Health Information System Tahun 2011-2014”. Jakarta. https://www.google.co.id. Diakses pada 2 April 2015.

[10] Latjamudin, A. 2005. Analysis and Designing Information System. Yogyakarta: Graha Ilmu. 
[11] Menkes RI. 2007. Permenkes RI Nomor 377/MENKES/SK/III/2007 tentang Standar Profesi Perekam Medis dan Informasi Kesehatan. Jakarta. http://bpmpt.jabarprov.go.id. Diakses 2 April 2015.

[12] Menkes RI. 2008. Permenkes RI No.269/MENKES/PER/III/2008 tentang Rekam Medis. Jakarta. http://www.apikes.com. Diakses 2 April 2015.

[13] Menkes RI. 2008. Permenkes RI No.749a/MENKES/PER/III/1989 tentang Rekam Medis. Jakarta. http://jdih.pom.go.id. Diakses 2 April 2015
[14] Menkes RI. 2014. Permenkes RI Nomor 75 Tahun 2014 tentang Pusat Kesehatan Masyarakat. Jakarta. http://www.jkn.kemkes.go.id. Diakses 2 April 2015.

[15] Pressman, D. Roger S. 2010. Pendekatan Praktisi Rekayasa. Perangkat Lunak. Edisi 7. Penerbit Andi. Yogyakarta 